\title{
Predicting Wood Decay in Eucalypts Using an Expert System and the IML-Resistograph Drill
}

\author{
Denise M. Johnstone, Peter K. Ades, Gregory M. Moore, and Ian W. Smith
}

\begin{abstract}
The evaluation of decayed wood in a tree trunk is essential for hazard tree assessment in arboriculture. In this study, an IML-Resistograph was highly successful as a field instrument in its ability to locate and predict the presence of decay in the trunk wood of eucalypts. A system for using the IML-Resistograph to estimate the area of decay in the cross-section of a eucalypt was evaluated for field use. The data from the IML-Resistograph F300S can be used as part of an expert system to estimate the area of wood decay in a cross-section of a standing eucalypt.
\end{abstract}

Key Words. Eucalypts; hazard trees; Resistograph; tree failure; tree risk analysis; wood decay.

The decay of wood within a tree trunk is often the cause of tree failure. There are many field devices for measuring decay in trees and they vary greatly in the principles on which they function. See Table 1 for a summary of devices in relation to their portability, invasiveness, reliability, cost, and ease of use. The most accurate of these instruments now generate a tomographic image using radar, sound, thermography, or electrical conductivity. However, these instruments are expensive and are dependent on the complexity of the algorithm that is used to convert raw data to an image for their accuracy.

In this research, an expert system was developed to predict the amount of wood decay in eucalypts using the less costly IML-Resistograph drill. The Resistograph measures mechanical resistance as a small drill bit moves through wood. Data from the Resistograph are recorded in the form of a graph. There are no units of measurement for the mechanical resistance shown by the drill, but the distance on the graph is the actual distance drilled in centimeters. A disadvantage with the Resistograph is it can provide a substrate for further decay in the wood of trees with preexisting decay because the shavings from drilling are left in the hole by the device (Kersten and Schwarze 2005).

\section{MATERIALS AND METHODS}

Experiments were conducted on trees at three different sites. Data were collected from an urban location, a forest, and a plantation site. Preliminary experiments were carried out on a Eucalyptus praecox Maiden (Expt. 1) and four Eucalyptus radiata Sieber ex D.C (Expt. 2). The tree species used in the primary experiment (Expt. 3) was Eucalyptus globulus subsp. pseudoglobulus Naudin ex Maiden. Eucalyptus globulus is widely planted as a specimen tree in countries as diverse as the United States, Palestine, India, Italy, and Brazil (Tyrell 1999). Eucalyptus globulus was therefore an ideal choice for the primary experiment.

Data from the Resistograph were compared with the appearance of wood decay in a tree cross-section. Wood decay was defined as wood displaying clear changes in texture, structure, and color, that is, decay from the intermediate stage through to advanced decay (Harris et al. 2004). An absence of wood was also treated as decay.

Data from the Resistograph used on the Eucalyptus praecox were observed to indicate decay on the graph traces when there was significant "yield" on the graph in relation to the rest of the trace and a lack of "peaks" on the graph associated with growth increments (Figure 1A and B). Data from a Resistograph used on the Eucalyptus radiata were then used to predict where decay was occurring without reference to the cut stem (Figure 2A and B). Subsequent to this, data from a Resistograph used on the Eucalyptus globulus subsp. pseudoglobulus were used not only to predict decay, but to predict how far decay may extend beyond the data collection points in the entire trunk cross section (Figure $3 \mathrm{~A}$ and $\mathrm{C}$ ).

To predict decay beyond the immediate point of data collection, an "expert system" was devised using the compartmentalization of decay in trees (or CODIT) model from Shigo (1979) in combination with raw data from the IMLResistograph. The method is an "expert system" because it relies on an expert knowledge of models of decay in trees. In Shigo's model, the tree resists the spread of decay within compartment walls 1, 2, 3, and 4 (Shigo 1979). "Wall 4" in Shigo's model is of particular importance. In the CODIT 
Table 1. Summary of the advantages and disadvantages of devices that measure wood decay.

\begin{tabular}{|c|c|c|c|c|c|}
\hline Type of device & $\begin{array}{l}\text { Ease of } \\
\text { interpreting results }\end{array}$ & Relative cost & $\begin{array}{l}\text { Reliability } \\
\text { in Eucalypts }\end{array}$ & $\begin{array}{l}\text { Invasiveness } \\
\text { in Eucalypts }\end{array}$ & Portability \\
\hline $\mathrm{X}$-ray diffraction & High $^{1}$ & High $^{1}$ & $\mathrm{High}^{2}$ & $\mathrm{High}^{3}$ & Low $^{1,2,4}$ \\
\hline Thermal and microwave & $\operatorname{High}^{1}$ & $\operatorname{High}^{1}$ & Probably high ${ }^{1}$ & Low $^{1}$ & Low $^{1}$ \\
\hline Imaging nuclear magnetic resonance & $\operatorname{High}^{1}$ & Very high ${ }^{1}$ & Probably high ${ }^{1}$ & Low $^{1}$ & Low $^{1}$ \\
\hline Imaging neutron imaging & $\operatorname{High}^{1}$ & Very high $^{1}$ & Probably high ${ }^{1}$ & Low $^{1}$ & Low $^{1}$ \\
\hline Transmission acoustic devices & Moderate ${ }^{5-7}$ & Low $^{7}$ & Unknown & Moderate $^{7,8}$ & $\mathrm{High}^{5,7-9}$ \\
\hline Constant feed drills & $\operatorname{High}^{8,10-12,24}$ & Low $^{11}$ & Probably high $^{24}$ & Moderate $^{12,13}$ & $\operatorname{High}^{8,10-12}$ \\
\hline Compression meters & Moderate ${ }^{10,14,15}$ & Low $^{11}$ & Moderate $^{16,17}$ & Moderate $^{15}$ & $\operatorname{High}^{10,15}$ \\
\hline Electrical conductivity & Moderate $^{8,10,18}$ & Low $^{19}$ & Low $^{20}$ & Moderate $^{8,10}$ & $\operatorname{High}^{8,10,21}$ \\
\hline Breaking core samples & Low $^{22,26}$ & Low $^{22}$ & Unsuitable $3,22,26$ & $\mathrm{High}^{22}$ & $\mathrm{High}^{22}$ \\
\hline Computerized tomography & $\operatorname{High}^{1,23,25}$ & $\operatorname{High}^{1}$ & Probably high ${ }^{1,20,23,25}$ & Low $^{1,23,25}$ & $\operatorname{High}^{23,25}$ \\
\hline
\end{tabular}

References: 1. Bucur 2003, 2. Evans et al. 1995, 3. Downes et al. 1997, 4. Bergsten et al. 2001, 5. Ouis 2003, 6. Mishiro 1996, 7. Wade 1975, 8. Nicolotti and Migietta 1998, 9. Smiley and Fraedrich 1992, 10. Seaby 1991, 11. Isik and Li 2003, 12. Rinn et al. 1996, 13. Kersten and Schwarze 2005, 14. Barrett 1987, 15. Cown 1978, 16. Moura et al. 1987, 17. Greaves et al. 1996, 18. Harris 1992, 19. Blazé 1992, 20. Wilkes and Heather 1983, 21. Shigo 1991, 22. Mattheck et al. 1995, 23. Nicolotti et al. 2003, 24. Costello and Quarles 1999, 25. Gilbert and Smiley 2004, 26. Matheny et al. 1999.

model "wall 4" is formed in the annual ring by the cambium after injury and resists the outward spread of decay from the center of the tree (Shigo 1979). Therefore, rather than predicting decay would be present in a straight line from one graph trace to another, the line was predicted following a notional growth ring. Diagrams of each cross-section were drawn in reference to the CODIT model and the interpretation of raw data from the Resistograph. The diagrams were used to predict the area of decay in millimeters squared in a crosssection (Figure 3A).

The E. globulus subsp. pseudoglobulus were felled and cross-sections were retained. The trunk sections were traced on clear plastic with observed cavities, decayed wood, and sound wood clearly marked. The drawings were photoreduced when necessary. The areas of the two drawings, predicted (using the expert system) and actual (from tracing the section), were then compared (Figure 3A and B). The area of the predicted cross-section was estimated as for a circle of the same radius, whereas the area of predicted decay was calculated using a dot matrix grid on overhead transparency paper and counting dots spaced $2 \mathrm{~mm}(0.08 \mathrm{in})$ apart. The area of the actual cross-section and the decay in the cross-section were calculated using the same dot grid.

Simple linear regression analyses testing the dependence of actual and predicted decayed wood were calculated using the software package SAS (Statistical Analysis System) version 8.2. For the data from the trees, simple regression analysis tested the dependence of:

1. Predicted area of decay in millimeters squared (as part of the expert system) for each section on the actual area of decay in the same tree sections;

2. Predicted linear distance of decay in millimeters across each section on the actual linear distance of decay in the same sections; and
3. Predicted location of decay in millimeters from the bark to the decay for each section on the actual location of decay in the same sections.

\section{RESULTS}

The results from the E. globulus subsp. pseudoglobulus in Expt. 3 suggest that the expert system can be used to predict the area of decay in a trunk cross-section of a eucalypt. A statistically very significant relationship was established between the predicted total area of decay in a wood section using the expert system and the actual area of decay (Figure 4). In this experiment, an analysis of variance of predicted and decayed area data indicated that $76 \%$ of the variation in the actual data set could be explained by the predicted decayed area in the cross-section $(P<0.0001, n=17)$. In terms of the percentage area of decay, the expert system overestimated decay by up to $7 \%$ (on average $4 \%$ ) and underestimated decay by up to $9 \%$ (on average $3 \%$ ). The percentage area of decay was predicted within a total range of $16 \%(-9 \%$ to $+7 \%$ ) and the decay in the sections was between $1 \%$ and $15 \%$ of the total area. In nine of the 17 samples, the expert system overestimated the percentage area of decay; in seven samples, it underestimated decay; and in one, the percentage was the same. This is a very good level of accuracy, particularly in trees that were quite small (diameter at $1.3 \mathrm{~m}$ [4.3 ft] of $198 \mathrm{~mm}$ [7.9 in], $132 \mathrm{~mm}$ [5.3 in], and $212 \mathrm{~mm}$ [8.5 in]).

There did appear to be two outlying points in the data set, but the two samples had the most decay of any cross-section in the data set. The test trees were small as previously stated and hence these points were not removed, because the more decayed samples are more representative of decayed trees that are usually larger. Although the data set for the number of samples is quite small $(n=17)$, the statistical relationship 

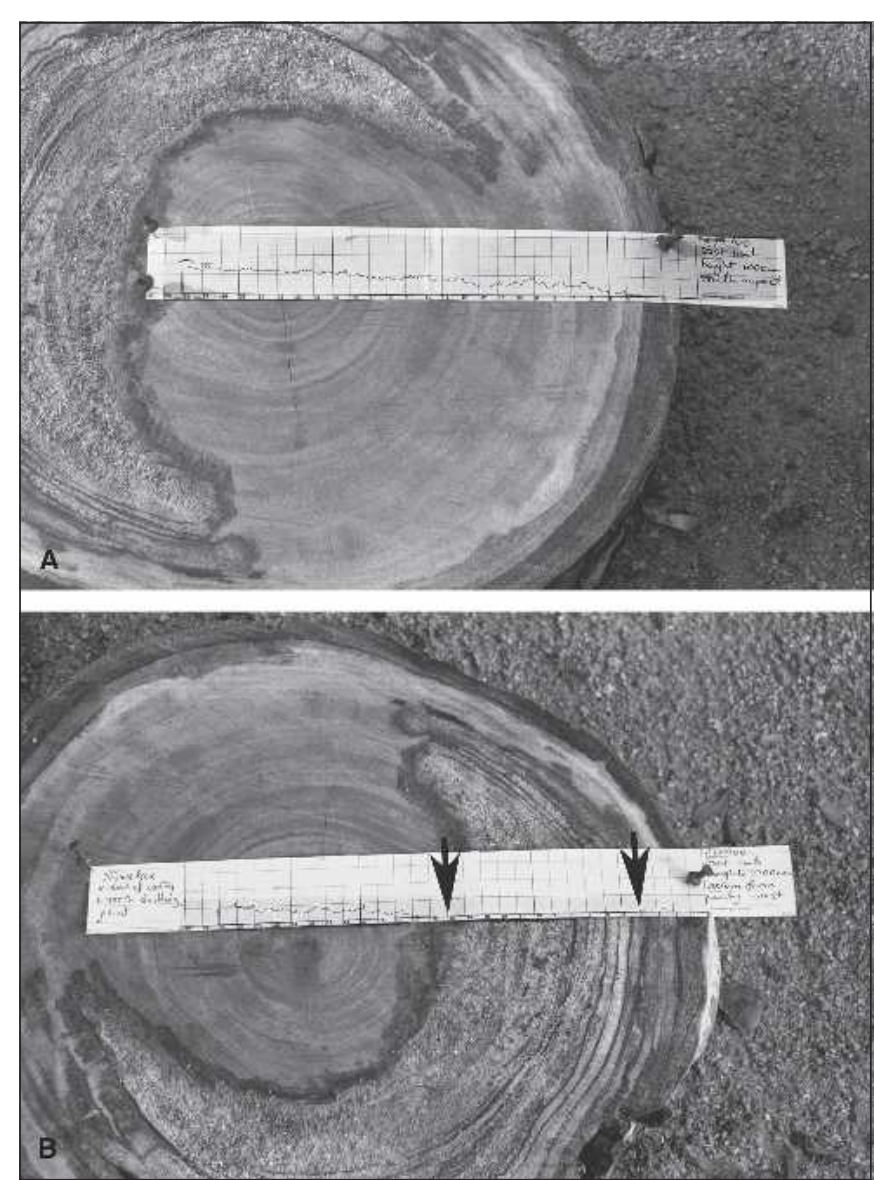

Figure 1. (A) Eucalyptus praecox cross-section at $1 \mathrm{~m}$ (3.3 ft) in height on the east limb, southern aspect, Expt. 1. This photograph shows the graph trace positioned at drill location with the drilling direction from right to left. The wood is entirely sound at the point of drilling. (B) Eucalyptus praecox cross-section at $1 \mathrm{~m}$ (3.3 ft) in height on the east limb northwestern aspect, Expt. 1. This photograph shows the graph trace positioned at drill location and the drilling direction from right to left. The wood is decayed between 4 ( $1.6 \mathrm{in}$ ) and $15 \mathrm{~cm}$ ( $6 \mathrm{in}$ ) along the graph trace as indicated by the arrows.

is significant and further sampling may establish a stronger relationship.

A statistically significant relationship was also established between the predicted linear distance in millimeters of decay in a wood section using the IML-Resistograph F300S and the actual linear distance of decay in a wood section (Figure 5). An analysis of variance of linear decay data indicated that $40 \%$ of the variation in predicted linear distance in millimeters could be explained by the actual linear distance in $\mathrm{mm}$ $(P=0.002, n=30)$.

Finally, a statistically very significant relationship was also established between the predicted linear distance in millimeters to decay in a wood section from the bark using the
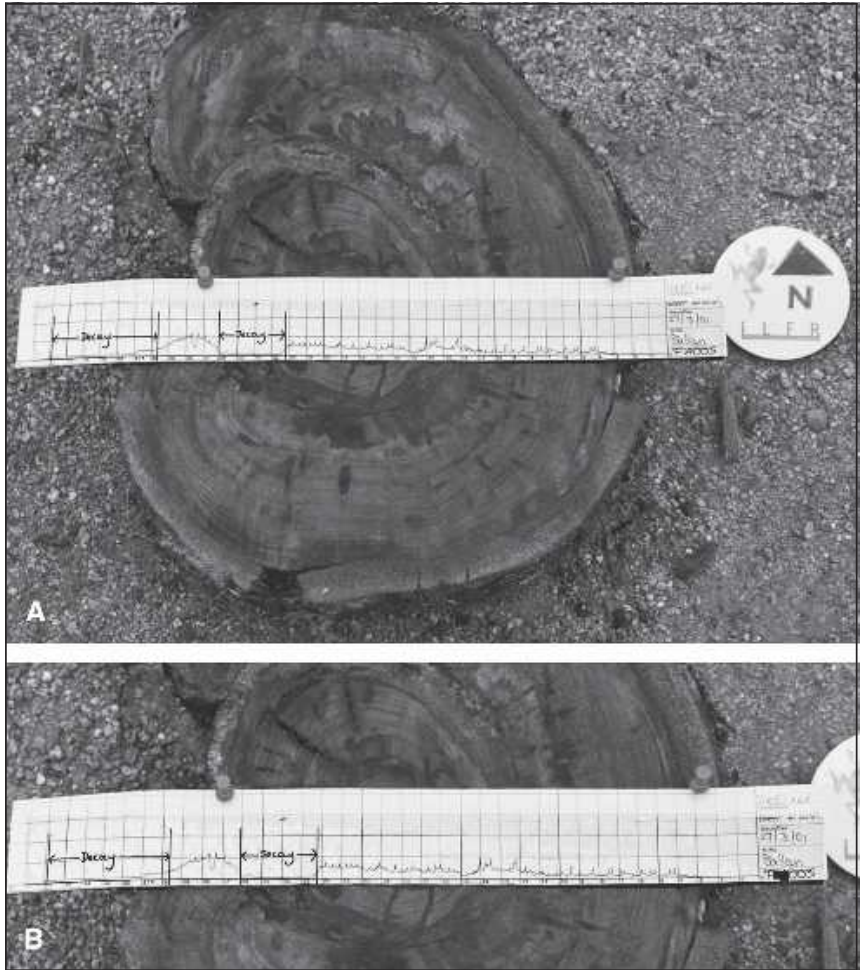

Figure 2. Decay predictions on IML-Resistograph graph trace placed on the drilled location on the Eucalyptus radiata, tree 1, Expt. 2, $0.5 \mathrm{~m}$ (1.7 ft) in height. The photograph shows the east to west aspect as drilled with the IML-Resistograph F400S. (A) The whole section; (B) an enlargement of the graph trace on the section. These photographs indicate the accuracy of the decay prediction in Expt. 2.

IML-Resistograph F300S and the actual linear distance in millimeters to decay from the bark in a wood section (Figure $6)$. In fact, $30 \%$ of the variation in predicted distance to decay could be explained by the actual distance to decay $(P<$ 0.0001, $n=56$ ).

\section{DISCUSSION}

The data produced by the IML-Resistograph F300S is a graph trace that measures the amplitude of drilling resistance on a strip chart. The IML-Resistograph F300S strip charts show growth rings or clearly defined earlywood and latewood boundaries in a tree as periodic peaks in the graph trace when they are present in a tree (Figures 1 and 2). The location of decayed wood can be observed on the strip chart by plotting the yield in the graph trace and also by the absence of periodic peaks (or growth rings if present) on the graph trace. The location of decay in a linear direction across a wood section can be plotted using this technique (Figure 2).

Samples in the experiments were not unbiased in these experiments in that they all had decay within the wood sec- 


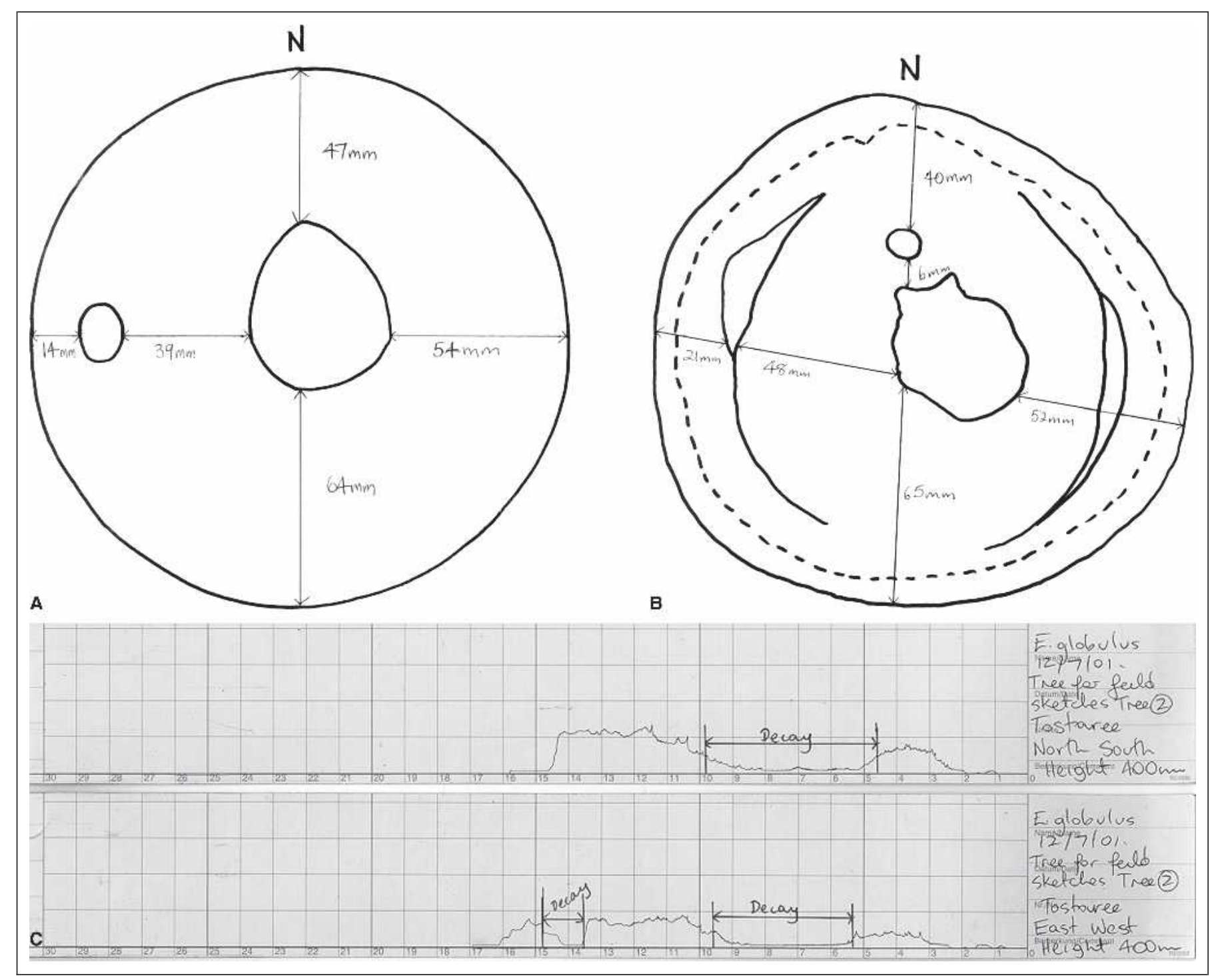

Figure 3. Eucalyptus globulus subsp. pseudoglobulus, cross-sectional diagrams and graph traces, tree 2, Expt. 3. This figure shows the tree 2 cross-section at $0.4 \mathrm{~m}$ (1.3 ft) in height from Expt. 3. (A) A drawing based on graph trace data from IML-Resistograph F300S. Raw data (C) is shown immediately above and (B) top right shows a drawing based on the actual tracings. Enclosed areas represent decayed wood; the dotted line is the division between bark and wood

tions. Choosing samples that were not decayed would have required less accuracy from the instruments. Therefore, samples that did not contain decay (only one, tree 1, $1.2 \mathrm{~m} \mathrm{[4}$ $\mathrm{ft}$ ] in height in Expt. 3) were removed from analysis.

A combination of raw data from the IML-Resistograph F300S and a sound knowledge of the principles of the CODIT model (Shigo 1979) allows accurate quantitative prediction of decay in an entire cross-section of a tree. This expert system relies on experience in the use of the IML-Resistograph F300S and knowledge of the CODIT model. It is assumed that data collection using the expert system would be carried out by a qualified arborist, who was trained in the interpre- tation of the Resistograph traces, as was the case in this study. Diagrams that are roughly to scale are drawn using IMLResistograph F300S data and the CODIT model (Figure 3). From these diagrams, the area of decay in a cross-section can be calculated in millimeters squared. The IML-Resistograph F300S used in conjunction with the expert system described in this report was therefore very successful as a tool for predicting decay in a wood cross-section. Results for the prediction of decay using the IML-Resistograph in E. globulus also proved to be more accurate than when using a portable drill by $\approx 12 \%$ in a previous study (Costello and Quarles 1999). 


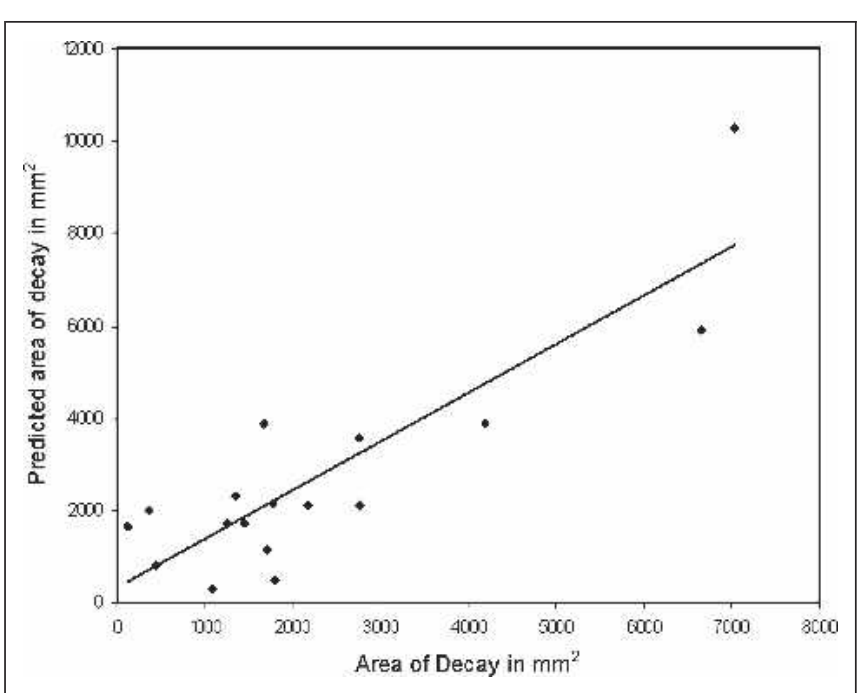

Figure 4. Predicted total area of decay using the expert system in millimeters squared versus total actual area of decay in millimeters squared in Expt. 3. Tree cross-sections from Eucalyptus globulus subsp. pseudoglobulus. Trend line $=$ linear regression. $P<0.0001, r^{2}=0.7584, n=17$.

It appears the IML-Resistograph is successful in the quantitative assessment of decay in trees and thus has great potential to the arboricultural industry. The IML-Resistograph could reduce the unnecessary removal of trees and also pre-

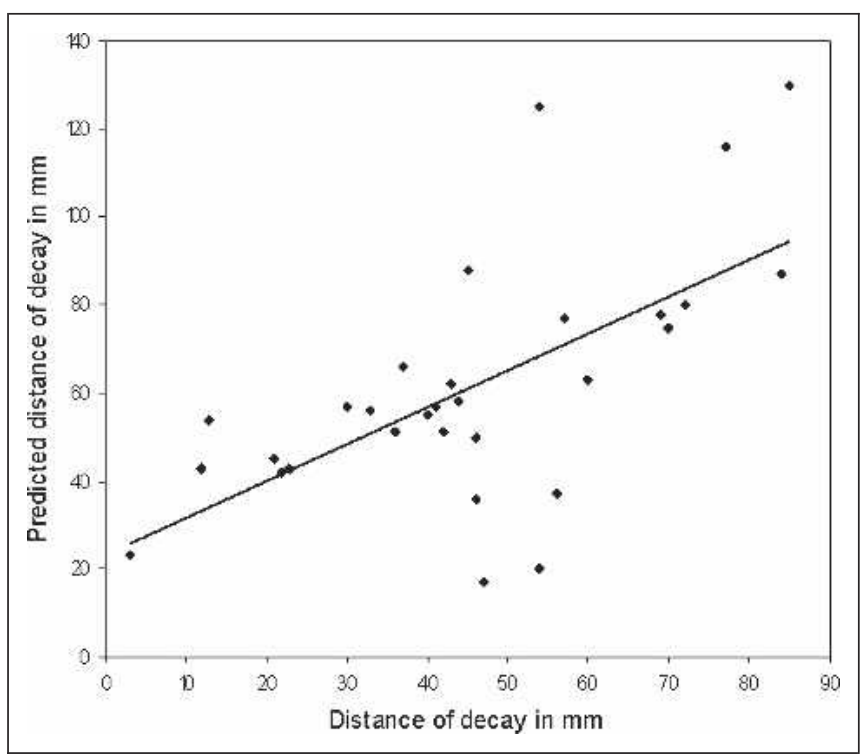

Figure 5. Predicted distance of decay using the IMLResistograph F300S versus actual distance of decay, Expt. 3. Predicted linear distance of decay from bark to bark in millimeters from the IML-Resistograph F300S data versus actual linear distance of decay from bark to bark in millimeters. Tree cross-sections from Eucalyptus globulus subsp. pseudoglobulus. Trend line = linear regression. $P=0.002, r^{2}=0.402, n=30$.

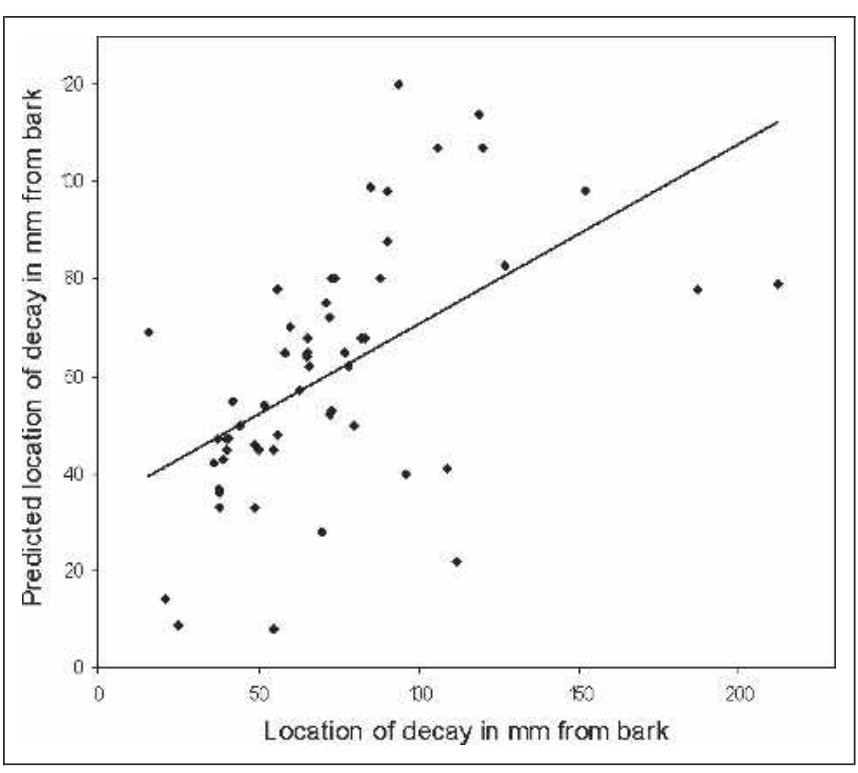

Figure 6. Predicted location of decay from IMLResistograph F300S versus actual location of decay, Expt. 3. Distance to decay from bark in millimeters from IMLResistograph F300S data versus actual linear distance to decay from bark in millimeters. Tree cross-sections from Eucalyptus globulus subsp. pseudoglobulus. Trend line = linear regression. $P<0.0001, r^{2}=0.3003, n=56$.

vent the retention of trees that may be dangerous. This instrument is relatively inexpensive and quick to use compared with "high-tech" options for decay detection such as sonic tomography. In fact, this study suggests the IMLResistograph in conjunction with the expert system may be less variable (16\%) than the Picus Sonic Tomograph $(23 \%$, Gilbert and Smiley 2004) for estimating the percentage area of decay in a wood section. Problems with the IMLResistograph include the fact that the use of the instrument can spread decay organisms in the wood of trees because the shavings from drilling are left in the hole (Kersten and Schwarze 2005). This would be a serious problem if it were being used for hazard tree assessment because the device may cause the tree to become more hazardous. Research needs to be done on whether removing the shavings from the hole made by the IML-Resistograph would solve this problem.

Acknowledgment. We acknowledge the support of the Department of Sustainability and Environment, Victoria, Australia, for the use of some of their plantation trees for this research.

\section{LITERATURE CITED}

Barrett, D.K. 1987. Portable 'compression strength meter'; a tool for the detection and quantification of decay in trees. Arboricultural Journal 11:313-322.

Bergsten, U., J. Lindeberg, A. Rindby, and R. Evans. 2001. Batch measurements of wood density on intact or pre- 
pared drill cores using x-ray microdensitometry. Wood Science and Technology 35:435-452.

Blazé, K. 1992. Electronic assessment of tree condition, pp. 135-145. In Scientific Management of Plants in the Urban Environment. Moore, G., May, P., Hitchmough, J., Delpratt, J., Kenyon, P., and P. Esdale, Eds. Conference Proceedings. Centre for Urban Horticulture, Melbourne.

Bucur, V. 2003. Nondestructive Characterization and Imaging of Wood. Berlin, Springer-Verlag. 354 pp.

Costello, L., and S. Quarles. 1999. Detection of wood decay in blue gum and elm: An evaluation of the IMLResistograph ${ }^{\circledR}$ and the portable drill. Journal of Arboriculture 25:311-317.

Cown, D.J. 1978. Comparison of the pilodyn and torsiometer methods for the rapid assessment of wood density in living trees. New Zealand Journal of Forestry Science 8: 384-391.

Downes, G.M., I.L. Hudson, C.A. Raymond, G.H. Dean, A.J. Michell, L.R. Schimleck, R. Evans, and A. Muneri. 1997. Sampling Plantation Eucalypts for Wood and Fibre Properties. CSIRO Publishing, Canberra. 132 pp.

Evans, R., G. Gartside, and G. Downes. 1995. Present and prospective use of Silviscan-An instrument for the rapid measurement of wood properties. Research Report, Melbourne, The CRC for Hardwood Fibre \& Paper Science: 47: 4 pp.

Gilbert, E., and E. Smiley. 2004. Picus sonic tomography for the quantification of decay in white oak (Quercus alba) and hickory (Carya spp.). Journal of Arboriculture 30: 277-281.

Greaves, B.L., N.M.G. Borralho, C.A. Raymond, and A. Farrington. 1996. Use of a Pilodyn for the indirect selection of basic density in Eucalyptus nitens. Canadian Journal of Forest Research 26:1643-1650.

Harris, R.W. 1992. Arboriculture. Integrated Management of Landscape Trees, Shrubs, and Vines. 2nd ed. Prentice Hall, NJ. 674 pp.

Harris, R.W., J.R. Clark, and N.P. Matheny. 2004. Arboriculture. Integrated Management of Landscape Trees, Shrubs, and Vines. 4th ed. Prentice Hall, NJ. 578 pp.

Isik, F., and B. Li. 2003. Rapid assessment of wood density of live trees using the IML-Resistograph for selection in tree improvement programs. Canadian Journal of Forest Research 33:2426-2435.

Kersten, W., and F.W.M.R. Schwarze. 2005. Development of decay in the sapwood of trees wounded by the use of decay-detecting devises. Arboricultural Journal 28: 165-181.

Matheny, N., J. Clark, D. Attewell, K. Hillery, A. Graham, and G. Posner. 1999. Assessment of fracture moment and fracture angle in 25 tree species in the united states using the fractometer. Journal of Arboriculture 25:18-23.
Mattheck, C.G., H. Breloer, K.A. Bethge, W.A. Albrecht, and A.W. Zipse. 1995. Use of the fractometer to determine the strength of wood with incipient decay. Journal of Arboriculture 21:105-112.

Mishiro, A. 1996. Effect of density on ultrasonic velocity in wood. Mokuzai Gakkai Shi 42:887-894.

Moura, V.P.G., R.D. Barnes, and J.S. Birks. 1987. A comparison of three methods of assessing wood density in provenances of Eucalyptus camaldulensis Dehnh. and other Eucalyptus species in Brazil. Australian Journal of Forest Research 17:83-90.

Nicolotti, G., and P. Miglietta. 1998. Using high-technology instruments to assess defects in trees. Journal of Arboriculture 24:297-302.

Nicolotti, G., L.V. Socco, R. Martinis, A. Godio, and L. Sambuelli. 2003. Application and comparison of three tomographic techniques for detection of decay in trees. Journal of Arboriculture 29:66-77.

Ouis, D. 2003. Non-destructive techniques for detecting decay in standing trees. Arboricultural Journal 27:159-177.

Rinn, F., F.H. Schweingruber, and E. Schar. 1996. IMLResistograph and x-ray density charts of wood comparative evaluation of drill resistance profiles and $\mathrm{x}$-ray density charts of different wood species. Holzforschung 50: 303-311.

Seaby, D.A. 1991. Recent advances in detection of wood decay, pp. 168-176. In Research for Practical Arboriculture. Hodge, S.J., Ed. HMSO. University of York.

Shigo, A.L. 1979. Tree decay: An expanded concept. USDA Forest Service Information Bulletin 419. 72 pp.

- 1991. Modern Arboriculture, Shigo \& Trees, New Hampshire. 421 pp.

Smiley, E.T., and B.R. Fraedrich. 1992. Determining strength loss from decay. Journal of Arboriculture 18:201-204.

Tyrell, I. 1999. True Gardens of the Gods: Californian-Australian Environmental Reform. University of California Press, California. 327 pp.

Wade, P.J. 1975. The Fujikura-Arborsonic Decay Detector Concept, Development \& Operation. Fujikura Europe Limited. $11 \mathrm{pp}$.

Wilkes, J., and W.A. Heather. 1983. Correlation of resistance to a pulsed current with several wood properties in living eucalypts. New Zealand Journal of Forestry Science 13: 139-145.

Denise M. Johnstone (corresponding author)

Lecturer, School of Resource Management

Faculty of Land and Food Resources

University of Melbourne

500 Yarra Boulevard

Richmond, Victoria, 3121, Australia

denisej@unimelb.edu.au 
Peter K. Ades

Senior Lecturer

School of Forest and Ecosystem Science

Faculty of Land and Food Resources

The University of Melbourne

Parkville, Victoria, 3010, Australia

Gregory M. Moore

Head of School

School of Resource Management

Faculty of Land and Food Resources

University of Melbourne

500 Yarra Boulevard

Richmond, Victoria, 3121, Australia

Ian W. Smith

Senior Research Fellow

School of Forest and Ecosystem Science

Faculty of Land and Food Resources

University of Melbourne

P.O. Box 137

Heidelberg, Victoria, 3084, Australia

Résumé. L'évaluation du bois carié dans le tronc est essentielle dans le diagnostic des arbres dangereux en arboriculture. Dans cette étude, un Résistographe-IML s'est avéré hautement probant comme instrument sur le terrain, et ce dans sa capacité à localiser et à prédire la présence de carie dans le bois du tronc d'eucalyptus. Un système pour l'emploi du Résistographe-IML dans l'estimation de la zone cariée de la section transversale d'un eucalyptus a été mis à l'essai sur le terrain. Les données du Résistographe-IML F300S peuvent être utilisées comme composante d'un système d'expertise pour évaluer la superficie de bois carié au sein d'une section transversale d'un eucalyptus donné.

Zusammenfassung. Für die Bewertung eines Gefahrenbaumes in der Baumpflege ist die Messung von krankem und befallenem Holz sehr wichtig. In dieser Studie wurde mit großem Erfolg ein IMLResistograph als Feldinstrument zur Lokalisierung und Bestimmung von Fäulnis im Stamm eines Eukalyptus eingesetzt. Hier wurde ein System zur Bestimmung von Fäulnisausdehnung innerhalb des Stammes von Eukalyptusbäumen auf seine Tauglichkeit als Feldinstrument getestet. Die Daten von dem IML-Resistographen F 300S können als Teil eines Expertensystems zur Bestimmung von Fäule in stehenden Eukalyptusbäumen verwendet werden.

Resumen. La medición de la descomposición de la madera del tronco es esencial para la evaluación del riesgo del árbol en la arboricultura. En este estudio, un Resistógrafo IML fue altamente exitoso como un instrumento de campo en su habilidad para localizar y predecir la presencia de descomposición en la madera del tronco de eucaliptos. Se evaluó un sistema para usar el Resistógrafo en el campo con el fin de estimar el área de descomposición en la sección trasversal de un eucalipto. Los datos del Resistógrafo IMLF300S pueden ser usados como parte de un sistema experto para estimar el área de decaimiento en la madera en una sección transversal de un eucalipto en pié. 